\title{
Sorption of Sulfachloropyridazine in Brazilian Soils
}

\author{
Alessandra Paula Vieira, Susanne Rath and Anne Hélène Fostier* \\ Instituto de Química, Universidade Estadual de Campinas, 13083-970 Campinas-SP, Brazil
}

\begin{abstract}
Sulfonamides are among the most widely employed antibacterial in veterinary medicine. Because a substantial proportion of sulfonamides are excreted unchanged as parent compounds after administration or are excreted as their metabolites through urine and feces, their presence in soils is a matter of concern. Adsorption and desorption are important processes that influence the transport, transformation and bioavailability of antimicrobials in soils, and data related to sorption capacity are therefore needed for environmental risk assessments. The sorption potential of sulfachloropyridazine (SCP) was assessed in four Brazilians soils using batch equilibrium experiments. The adsorption/desorption data fit well Freundlich isotherms. The sorption coefficients $\left(K_{D}\right)$ ranged from 1.00 to $4.48 \mathrm{~cm}^{3} \mathrm{~g}^{-1}$, and the Freundlich adsorption coefficient $\left(\mathrm{K}_{\mathrm{F}}\right)$ ranged from 1.89 to $5.63 \mu \mathrm{g}^{1-1 / \mathrm{n}}\left(\mathrm{cm}^{3}\right)^{1 / \mathrm{n}} \mathrm{g}^{-1}$ showing that SCP adsorption is generally low in the studied soils. The results were compared with previously published data obtained for the sorption of other sulfonamides in the same four soils.
\end{abstract}

Keywords: veterinary drug, antimicrobial, sulfonamide, soil, sorption

\section{Introduction}

Antimicrobials are used as prophylactic and therapeutic agents to treat diseases in animals and humans. ${ }^{1-3}$ After administration to animals, a substantial proportion (30-90\%) of antimicrobials is excreted unchanged as parent compounds or as their metabolites through urine and feces. Antimicrobials and/or metabolites can therefore enter the environment directly from manure or indirectly when manure is applied in soils as fertilizer and remain biologically active in the environment. ${ }^{4-6}$ Antimicrobial resistance has become a global concern because antimicrobials present in soil and natural water can facilitate the proliferation of antimicrobial-resistant microorganisms. ${ }^{7,8}$ The Brazilian production of beef, pork and chicken in 2010 was approximately 24.5 million tons. This production should increase $51 \%$ by $2018 / 2019$, reaching 37 million $\mathrm{t}$ per year, and the exportation of chickens should increase $48.1 \%$ by 2020 , placing Brazil as the world's largest producer and exporter of chickens. ${ }^{9}$ This large production directly affects the domestic veterinary drug market, which reached approximately US\$ 4 billion in 2014. Among the different therapeutic classes, antimicrobial agents account for $16 \%$ of this market. ${ }^{10}$

*e-mail: fostier@iqm.unicamp.br
Sulfonamides are among the most widely employed antibacterial agents in veterinary medicine, primarily due to their low cost and relatively high efficacy in treating bacterial diseases. ${ }^{6}$ In New Zealand, both tylosin (a macrolide antibiotic) and the sulfonamides group account for approximately $17 \%$ of the total antimicrobials used in livestock operations, ${ }^{11}$ and in the USA, sulfonamides represent $2.3 \%$ of all the antibiotics used. ${ }^{12}$ In the UK and the Netherlands, sulfonamides are the second most widely used veterinary antimicrobials, accounting for approximately 82 and $75 \mathrm{t}$ per year, respectively. ${ }^{13}$ In Brazil, almost 90 different formulations containing sulfonamides are commercially available for veterinary applications. ${ }^{10}$

In the environment, the transport of chemicals to surface water and groundwater is primarily governed by sorption processes, which also play a central role in the transformation reactions and soil microbial interactions. ${ }^{11}$ Data related to sorption capacity are therefore needed for environmental risk assessments.

Antimicrobials are poly functional ionogenic compounds that can sorb to environmental solids at multiple receptor sites. Their structures are generally complex and can include nonpolar or polar neutral moieties/ groups and cationic or anionic groups. These compounds are therefore considered unique in that they sorb to environmental solids at multiple receptor sites via multiple 
interaction mechanisms, such as surface complexation, $\mathrm{H}$-bonding, cation bridging, ion-exchange and hydrophobic partitioning. ${ }^{14}$ Consequently, their sorption varies greatly with the soil physicochemical properties, particularly soil $\mathrm{pH}$, quantity and quality of organic matter and the types of minerals present. ${ }^{15}$ Notwithstanding the number of studies on the sorption of polyfunctional ionogenic compounds on soils, differences in experimental conditions and the absence of studies involving a large set of homologous compounds constitute obstacles in the development of predictive models of sorption. ${ }^{14}$

Among antimicrobials, sulfonamides have been largely studied, ${ }^{16,17}$ and sulfachloropyridazine (SCP) has occasionally been considered a model compound for this group. ${ }^{13,18}$

Sulfonamides are amphoteric compounds with two ionizable groups: the basic 4 -amine aromatic $\left(1.6<\mathrm{pKa}_{1}<2.6\right)$ and acid sulfonamide $\left(5.7<\mathrm{pKa}_{2}<8.0\right)$ moieties. ${ }^{19}$ In the environment, they are expected to be present in neutral (uncharged) and anionic (deprotonated) forms, with the latter being more abundant at higher $\mathrm{pH}$ values. ${ }^{6,13}$ Hydrophobic partitioning and electrostatic interactions can therefore be involved in the sorption process, and the accumulation and persistence of residual sulfonamides in soil depend on environmental parameters, including the soil $\mathrm{pH}$, the organic matter content of the soil, the cation exchange capacity (CEC) and the clay minerals. ${ }^{15}$

Overall, the sorption coefficients $\left(\mathrm{K}_{\mathrm{D}}\right)$ of sulfonamides in soils have been reported to fall in the range of 0.6 to $7.4 \mathrm{~L} \mathrm{~kg}^{-1}{ }^{6}$ These relatively low $\mathrm{K}_{\mathrm{D}}$ values indicate that sulfonamides would be mobile in soils, in accordance with their high water solubility and low $\log \mathrm{K}_{\mathrm{OW}}$. Nevertheless, Leal et al. ${ }^{20}$ reported highly variable $\mathrm{K}_{\mathrm{D}}$ values for sulfonamides in Brazilian soils, ranging from 0.7 to $70.1 \mathrm{~L} \mathrm{~kg}^{-1}$, with the highest value found for SCP. Due to the rainfall pattern and intensity, Brazilian soils are generally highly weathered with a low organic content $(<10 \%)$ and $\mathrm{pH}<5$.5. They are also typically rich in 1:1 clay minerals and oxides and hydroxides of $\mathrm{Fe}$ and $\mathrm{Al}$, and they have mostly pH-dependent net charges. ${ }^{20}$ Compared to soils from temperate regions, these differences in pseudo-climatic conditions can significantly influence the sorption potential. However, few studies have been reported regarding the sorption of sulfonamides in Brazilian soils, ${ }^{16,17,20}$ and the experimental conditions were not always the same for the studies.

Therefore, the objective of this work was to assess the sorption affinity of sulfachloropyridazine in four representative soils from the State of São Paulo (SP), Brazil, complementing previous studies conducted with some other sulfonamides in the same soils. ${ }^{16,17}$

\section{Experimental}

\section{Soil samples}

Sorption studies were conducted on four soils (N1, N2, S1 and S2) from São Paulo State. The soils were collected in 2005 from different locations and transferred to lysimeters $(1 \times 1 \times 2 \mathrm{~m})$ located in the experimental area of the Brazilian Agricultural Research Corporation (Embrapa), city of Jaguariúna, SP, Brazil, in which the soil profiles were reconstructed. The origins of the soils were as follows:

N1: sandy, city of Santa Rita do Passa Quatro, SP (21 ${ }^{\circ} 42^{\prime} 18.12^{\prime \prime} \mathrm{S}$ and $47^{\circ} 28^{\prime} 04.82^{\prime \prime} \mathrm{W}$, altitude $773 \mathrm{~m}$ ) (pasture).

N2: clay, city of Sertãozinho, SP $\left(21^{\circ} 05^{\prime} 20.44^{\prime \prime}\right.$ S and $47^{\circ} 48^{\prime} 10.73^{\prime \prime} \mathrm{W}$, altitude $538 \mathrm{~m}$ ) (sugar cane plantation).

S1: sandy-clay, city of Jaguariúna (22 $43^{\prime} 14.92^{\prime \prime} S$ and $47^{\circ} 01^{\prime} 14.20^{\prime \prime} \mathrm{W}$, altitude $617 \mathrm{~m}$ ) (citrus plantation).

S2: clay, city of Jaguariúna $\left(21^{\circ} 42^{\prime} 59.50\right.$ "S and $47^{\circ} 01^{\prime} 00.05^{\prime}$ 'W, altitude $609 \mathrm{~m}$ ) (covered with Brachiaria).

The soil samples used in this study were collected from each lysimeter in July 2010 at a depth of 0-20 cm, dried at room temperature, sieved to a particle size of $\leq 2 \mathrm{~mm}$ and stored in plastic bags maintained at room temperature until use. The physicochemical characteristics of each soil, provided by the Laboratory of Soil Fertility from the Agronomic Institute of Campinas, are presented in Table 1.

\section{Reagents}

All solvents were of HPLC grade, and all reagents were of at least analytical grade. Methanol was purchased from JT Baker, USA. Oxalic acid (purity $\geq 99 \%$ ) was purchased from Sigma Aldrich, Belgium. Calcium chloride was supplied by Vetec, Brazil. Water was obtained from a Milli-Q purification system (Millipore, USA). Sulfachloropyridazine (CAS 80-32-0, 99.4\%) was purchased from Fluka, USA. The molecular structure and some of the physicochemical properties of SCP are shown in Figure 1. The standard stock solution $\left(1000 \mathrm{mg} \mathrm{L}^{-1}\right)$ of SCP was prepared in methanol. Working solutions were prepared by the appropriate dilution of the standard stock solution in $0.01 \mathrm{~mol} \mathrm{~L}^{-1} \mathrm{CaCl}_{2}$.

\section{HPLC analysis}

For SCP determination, the chromatographic system included a Waters high performance liquid chromatograph (HPLC), model 510, equipped with a pump and a UV-Vis detector (model 486 Tunable Absorbance). 
Table 1. Physical and chemical properties of the selected soils

\begin{tabular}{|c|c|c|c|c|}
\hline \multirow{2}{*}{ Property } & \multicolumn{4}{|c|}{ Soil } \\
\hline & N1 & $\mathrm{N} 2$ & S1 & $\mathrm{S} 2$ \\
\hline $\mathrm{pH}$ & 5.0 & 4.9 & 4.1 & 4.4 \\
\hline Organic matter $/ \%$ & 1.53 & 2.88 & 2.48 & 3.23 \\
\hline Organic carbon / \% & 0.89 & 1.67 & 1.44 & 1.87 \\
\hline \multicolumn{5}{|l|}{ Texture } \\
\hline Sand / \% & 91.1 & 14.9 & 52.9 & 43.5 \\
\hline Silt $(0.053-0.002 \mathrm{~mm}) / \%$ & 1.8 & 30.2 & 10.5 & 7.0 \\
\hline Clay $(<0.002 \mathrm{~mm}) / \%$ & 6.2 & 54.6 & 36.2 & 49.2 \\
\hline Cation exchange capacity $(\mathrm{CEC}) /\left(\mathrm{mmol}_{\mathrm{c}} \mathrm{kg}^{-1}\right)$ & 19.3 & 52.7 & 51.9 & 66.0 \\
\hline
\end{tabular}

$\begin{array}{ll}\text { Molar mass } & 284.7 \mathrm{~g} \mathrm{~mol}^{-1} \\ & \\ \text { Solubility } & \mathrm{g} \mathrm{L}^{-1} 18 \\ \mathrm{pKa} 1 & 1.9^{21} \\ \mathrm{pKa} 2 & 5.4^{21} \\ \mathrm{~K}_{\mathrm{OW}} & 2.044^{22}\end{array}$

Figure 1. Structure and some physicochemical properties of sulfachloropyridazine.

Separations were performed on an $\mathrm{ACE}^{\circledR} \mathrm{C} 18$ $(250 \times 4.6 \mathrm{~mm}, 5 \mu \mathrm{m}$ particle size) column (ACT, Scotland). The elution was in isocratic mode at a flow

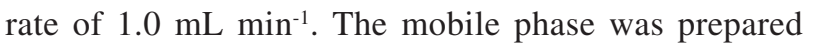
with methanol with $0.1 \%(\mathrm{v} / \mathrm{v})$ formic acid and water $(30: 70 \mathrm{v} / \mathrm{v})$. The quantification was performed at $260 \mathrm{~nm}$. A retention time of approximately 9 min was determined for SCP.

\section{HPLC method validation}

The HPLC method was validated in house by evaluating the following parameters: matrix effect, linear range, linearity, limit of quantification (LOQ), and intra- and inter-day precisions.

For each soil, the matrix effect was evaluated through fortification with SCP $\left(15 \mathrm{mg} \mathrm{L}^{-1}\right)$ of the supernatant obtained after the soil samples were equilibrated $(48 \mathrm{~h}$ at room temperature) with $0.01 \mathrm{~mol} \mathrm{~L}^{-1} \mathrm{CaCl}_{2}$, centrifuged, and filtered with $0.22-\mu \mathrm{m}$ membrane filters. The fortified extract was analyzed by HPLC, and the area obtained was compared with the area of the solution prepared at the same concentration level in $0.01 \mathrm{~mol} \mathrm{~L}^{-1} \mathrm{CaCl}_{2}$. All analyses were performed in duplicate.

The linearity and linear range were established through external calibration obtained by triplicate analyses of seven concentrations ranging from 1.0 to $40.0 \mathrm{mg} \mathrm{L}^{-1} \mathrm{SCP}$ in $0.01 \mathrm{~mol} \mathrm{~L}^{-1} \mathrm{CaCl}_{2}$.

The LOQ was determined as ten times the signal-tonoise ratio.

The intra-day and inter-day precisions were evaluated by analyzing the $0.01 \mathrm{~mol} \mathrm{~L}^{-1} \mathrm{CaCl}_{2}$ extracts $(1 / 5, \mathrm{~m} / \mathrm{v})$ obtained from each soil sample fortified with $20 \mathrm{mg} \mathrm{L}^{-1}$ SCP (equivalent to $100.0 \mu \mathrm{g} \mathrm{g}^{-1}$ of soil) after an apparent equilibrium time of $48 \mathrm{~h}$.

For intra-day precision, experiments were performed in sextuplicate, on the same day, by the same analyst and using the same method and equipment. The inter-day precision was determined using the same procedure described for the intra-day precision; however, the experiments were performed on three different days (sextuplicate tests during the first day and triplicate tests during the two other days). The intra- and inter-day precisions were expressed as the relative standard deviation (RSD).

\section{Sorption/desorption experiments}

The batch experiment method was used to determine the soil sorption and desorption constants of the four soils under study according to the OECD Test Guideline $106 .{ }^{23}$ All experiments were conducted in polypropylene vessels at room temperature $\left(20-25{ }^{\circ} \mathrm{C}\right)$ in the dark while being stirred horizontally (120 rpm).

Preliminary experiments were performed to assess the stability of SCP and its possible adsorption on the surface of the test vessels. For stability, $25 \mathrm{~mL}$ solutions of $0.01 \mathrm{~mol} \mathrm{~L}^{-1} \mathrm{CaCl}_{2}$ were fortified with $25 \mathrm{mg} \mathrm{L}^{-1} \mathrm{SCP}$, and stirring of the samples in the dark was maintained for $1,24,48,72,96,120$ and $144 \mathrm{~h}$; the SCP concentration was then determined by HPLC.

For each soil, batch kinetic experiments were conducted using the parallel method at the natural (unaltered) $\mathrm{pH}$ of the medium to determine the adsorption equilibrium 
time. ${ }^{21}$ For this purpose, $1 \mathrm{~g}$ of soil was mixed with $5 \mathrm{~mL}$ of $0.01 \mathrm{~mol} \mathrm{~L}^{-1} \mathrm{CaCl}_{2}$ in polypropylene tubes and shaken for $24 \mathrm{~h}$ for pre-equilibration. The mixture was then fortified with $25 \mathrm{mg} \mathrm{L}^{-1} \mathrm{SCP}$ and shaken from 0 to $144 \mathrm{~h}$. The analyses were performed after $0,2,4,8,24,48,72$, 96, 120 and $144 \mathrm{~h}$ contact time. Prior to the analyses, the samples were centrifuged at $6000 \times \mathrm{g}$ for $20 \mathrm{~min}$; the supernatant was filtered through a $0.22-\mu \mathrm{m}$ Millipore membrane filter, and the SCP was determined by HPLC. The percentage of SCP adsorbed onto soil was calculated and plotted as a function of time. To evaluate the kinetic sorption mechanism, the pseudo-second-order (equation 1) and Elovich (equation 2) models were tested.

The pseudo-second-order model (PSO) considers the sorption capacity to be proportional to the number of active soil sites occupied. In its linear form, this model can be expressed as follows:

$\frac{\mathrm{t}}{\mathrm{q}_{\mathrm{t}}}=\frac{1}{\mathrm{k}_{2} \mathrm{q}_{\mathrm{e}}^{2}}+\frac{\mathrm{t}}{\mathrm{q}_{\mathrm{e}}}$

In this model, $\mathrm{q}_{\mathrm{t}}\left(\mu \mathrm{g} \mathrm{g}^{-1}\right)$ is the sorbed concentration at the time $\mathrm{t}, \mathrm{q}_{\mathrm{e}}\left(\mu \mathrm{g} \mathrm{g}^{-1}\right)$ is the maximum sorbed concentration at equilibrium, and $\mathrm{k}_{2}\left(\mathrm{~g} \mathrm{\mu g}^{-1} \mathrm{~min}^{-1}\right)$ is the pseudo-secondorder rate constant for the kinetic model. The values of $\mathrm{q}_{\mathrm{e}}$ and $\mathrm{k}_{2}$ are then determined directly from the slope and intercept of the plot of $\mathrm{t} / \mathrm{q}_{\mathrm{t}}$ versus $\mathrm{t}$, respectively. ${ }^{22}$

The Elovich model (equation 2) assumes that the sorption kinetic occurs in a rapid initial process associated with the movement of the compound to the most accessible part of the sorbent, followed by a slower process due to particle diffusion into and out of the sorbent's micropores. ${ }^{24,25}$

$\mathrm{q}_{\mathrm{t}}=\frac{1}{\mathrm{Y}} \ln (\mathrm{XY})+\frac{1}{\mathrm{Y}} \ln \mathrm{t}$

In this model, $\mathrm{X}$ and $\mathrm{Y}$ are constants. The intercept $1 / Y \ln (X, Y)$ coincides with the sorbed quantity during the fast phase $\left(\mathrm{q}_{\text {fast }}\right)$, whereas the slope $(1 / \mathrm{Y})$ represents the slow sorption in relation to the duration of the second phase. ${ }^{23}$

For the sorption isotherms, $5 \mathrm{~mL}$ of $0.01 \mathrm{~mol} \mathrm{~L}^{-1}$ $\mathrm{CaCl}_{2}$ was added to $1.0 \mathrm{~g}$ of soil $(\mathrm{N} 1, \mathrm{~N} 2, \mathrm{~S} 1$ or $\mathrm{S} 2)$ in polypropylene tubes. After a $24 \mathrm{~h}$ pre-equilibration period, the samples were spiked with an appropriate volume of SCP solution to obtain five different concentrations in the range of 2 to $35 \mathrm{mg} \mathrm{L}^{-1}$, and the suspensions were shaken for $48 \mathrm{~h}$. Prior to the analyses, the samples were centrifuged at $6000 \times \mathrm{g}$ for $20 \mathrm{~min}$; the supernatant was filtered through a $0.22-\mu \mathrm{m}$ Millipore membrane filter, and the SCP was determined by HPLC. In each tube, the remaining soil was immediately used for desorption studies. For this purpose, $5 \mathrm{~mL}$ of $0.01 \mathrm{~mol} \mathrm{~L}^{-1} \mathrm{CaCl}_{2}$ was added to each remaining soil sample and the tubes were shaken for another $96 \mathrm{~h}$. The samples were centrifuged, and the supernatant was filtered through $0.22 \mu \mathrm{m}$ membrane filters before being analyzed by HPLC. All experiments were performed in triplicate. Blank soil samples revealed that none of the soils were contaminated with SCP $\left(\mathrm{LOD}=30.0 \mu \mathrm{g} \mathrm{L}^{-1}\right)$. A control sample consisting solely of SCP in $0.01 \mathrm{~mol} \mathrm{~L}^{-1} \mathrm{CaCl}_{2}$ was subjected to the same test procedure.

\section{Data analyses: sorption and desorption isotherms}

The amount of SCP adsorbed onto the soil (Cs, $\left.\mu \mathrm{g} \mathrm{g}^{-1}\right)$ after apparent equilibrium had been reached was calculated using equation 3 :

$\mathrm{C}_{\mathrm{s}}^{\mathrm{ads}}=\frac{\mathrm{V}_{0}}{\mathrm{~m}_{\mathrm{soil}}} \times\left(\mathrm{C}_{0}-\mathrm{C}_{\mathrm{aq}}^{\mathrm{ads}}\right)$

where $\mathrm{V}_{0}(\mathrm{~mL})$ is the initial volume of solution, $\mathrm{m}_{\text {soil }}(\mathrm{g})$ is the mass of soil, $\mathrm{C}_{0}\left(\mu \mathrm{g} \mathrm{mL} \mathrm{m}^{-1}\right)$ is the initial concentration

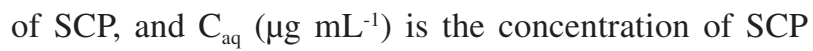
remaining in solution after apparent equilibrium has been reached.

All results were modeled using both linear and nonlinear Freundlich isotherms (equation 4):

$\log \mathrm{C}_{\mathrm{s}}=\log \mathrm{K}_{\mathrm{F}}+\frac{1}{\mathrm{n}} \times \log \mathrm{C}_{\mathrm{aq}}$

where $K_{F}\left(\mu g^{1-1 / n}\left(\mathrm{~cm}^{3}\right)^{1 / n} \mathrm{~g}^{-1}\right)$ is the Freundlich adsorption $\left(\mathrm{K}_{\mathrm{F}}{ }^{\text {ads }}\right)$ or desorption $\left(\mathrm{K}_{\mathrm{F}}{ }^{\text {des }}\right)$ coefficient and $1 / \mathrm{n}$ is the slope (Freundlich exponent or linearity factor, a constant depicting the sorption intensity). ${ }^{24}$ When $1 / n=1, K_{F}$ is equivalent to the distribution coefficient for sorption $\mathrm{K}_{\mathrm{D}}\left(\mathrm{cm}^{3} \mathrm{~g}^{-1}\right)$, which can be calculated using equation 5 :

$\mathrm{K}_{\mathrm{D}}=\frac{\mathrm{C}_{\mathrm{s}}}{\mathrm{C}_{\mathrm{aq}}}$

Because partitioning mechanisms can be complex for a number of organic compounds, primarily for nonionic compounds, the sorption coefficients can be normalized by the organic carbon content (OC\%), as shown in equation 6.

$\mathrm{K}_{\mathrm{OC}}=\mathrm{K}_{\mathrm{D}} \times \frac{100}{\% \mathrm{OC}}$

where $\mathrm{K}_{\mathrm{OC}}\left(\mathrm{cm}^{3} \mathrm{~g}^{-1}\right)$ is the normalized sorption coefficient. For this purpose, the percentage of organic carbon was 
calculated from the organic matter content (OM\%) by considering $\mathrm{OM} \%=1.724 \mathrm{OC} \%{ }^{25}$

\section{Results and Discussion}

\section{Method validation}

The analysis of the chromatograms did not indicate any interference in the four different soil sample matrices under the established experimental conditions, conferring adequate selectivity to the method. As an example, Figure 2 shows the chromatogram obtained for $15 \mathrm{mg} \mathrm{L}^{-1} \mathrm{SCP}$ in pre-equilibrated soil solution $\mathrm{S} 1$.

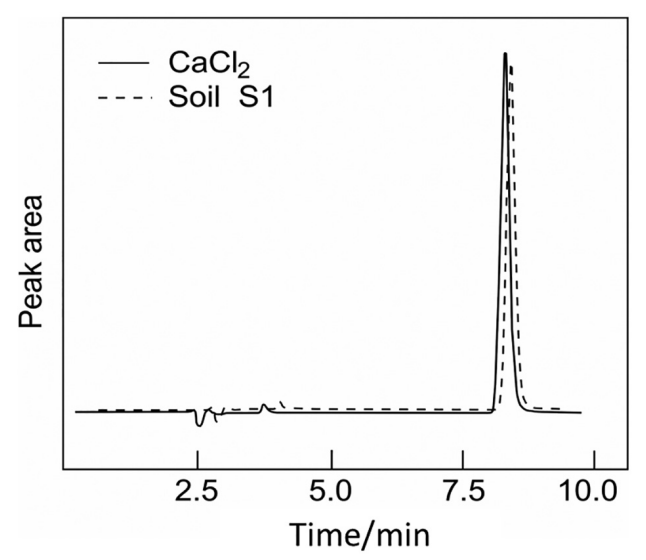

Figure 2. Chromatogram of $15 \mathrm{mg} \mathrm{L}^{-1} \mathrm{SCP}$ in $0.01 \mathrm{~mol} \mathrm{~L}^{-1} \mathrm{CaCl}_{2}$ and in pre-equilibrated soil solution $\mathrm{S} 1$.

In addition, it was verified that the slopes of the calibration curves obtained for SCP in $0.01 \mathrm{~mol} \mathrm{~L}^{-1} \mathrm{CaCl}_{2}$ and SCP in the soil extracts do not significantly differ (Student's $t$-test, 95\% confidence level), confirming the absence of the matrix effect. The results of the other validation parameters are presented in Table 2.

Control samples (25 mg SCP L-1 in $0.01 \mathrm{~mol} \mathrm{~L}^{-1} \mathrm{CaCl}_{2}$ ) were analyzed to evaluate the possible degradation and/or adsorption of SCP to the surface of the polypropylene tubes. A recovery of $98.7 \%$ was measured after $144 \mathrm{~h}$ of experimentation, indicating that SCP is stable in the medium over time with no sorption onto the tubes.
Kinetic study

Any mass transfer process between two phases (e.g., liquid/solid) can be modeled from a kinetic perspective. The kinetic sorption process involves three mechanisms: (i) transport of the sorbate to the solid surface; (ii) transfer through the liquid film adhered at the solid surface; (iii) interaction of the compound with the solid surface through chemical or physical interactions. ${ }^{26} \mathrm{An}$ appropriate kinetic model allows the determination of the time required to reach the sorption equilibrium and can also provide some information on the physical process involved in the sorption process. For each soil, the SCP equilibration time was established through a plot of sorption percentage versus time (0 to $8640 \mathrm{~min}$ ) (Figure 3).

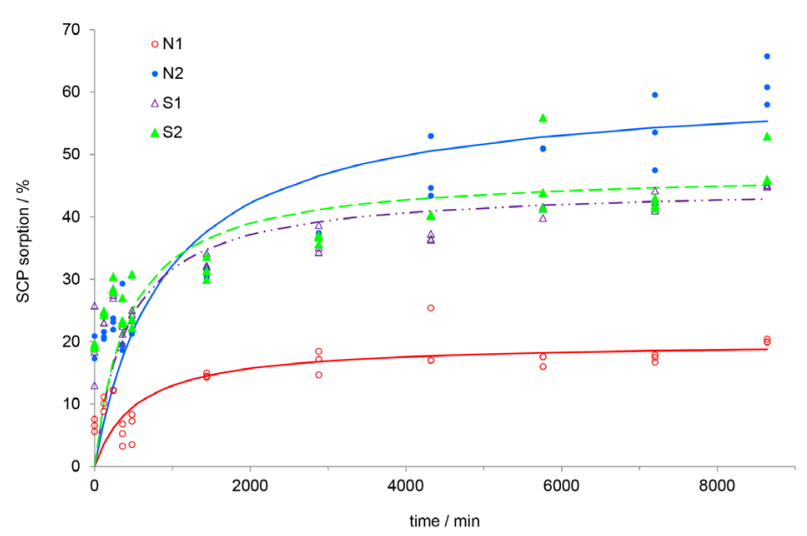

Figure 3. SCP sorption kinetics for soils N1, N2, S1 and S2. Markers correspond to experimental data and lines to PSO fitted data.

The sorption profile shows a two-stage sorption process: sorption increased quickly during the first eight hours, and then it increased slowly until approximately $48 \mathrm{~h}$ (2880 min) (apparent equilibration time). Many previous studies also found slow sorption for sulfonamides, primarily ranging from 12 to 48 h. ${ }^{11,13,27-29}$ The kinetic results were modeled using a pseudo-second-order model and using the Elovich model (data not shown). The best fit for the experimental results was achieved with the pseudo-second-order model ( $r>0.98)$, suggesting that sorption was primarily governed by the availability of

Table 2. Method validation parameters for the determination of SCP

\begin{tabular}{|c|c|c|c|c|}
\hline Soil & S1 & $\mathrm{S} 2$ & N1 & $\mathrm{N} 2$ \\
\hline Linear range / $\left(\mathrm{mg} \mathrm{L}^{-1}\right)$ & $1-40$ & $1-40$ & $1-40$ & $1-40$ \\
\hline Linearity (r) & 0.99 & 0.99 & 0.99 & 0.99 \\
\hline Intra-day precision ${ }^{\mathrm{a}} / \%$ & 6.2 & 5.9 & 7.8 & 5.1 \\
\hline Inter-day precision ${ }^{\mathrm{a}} / \%$ & 6.2 & 7.8 & 4.9 & 10.9 \\
\hline $\mathrm{LOQ} /\left(\mu \mathrm{g} \mathrm{L}^{-1}\right)$ & 50 & 60 & 50 & 60 \\
\hline
\end{tabular}

${ }^{\mathrm{a}}$ Fortification level: $100 \mu \mathrm{g} \mathrm{g}^{-1}$; LOQ: limit of quantification. 
sorption sites on the soil surfaces rather than the SCP concentration in the solution. ${ }^{22}$

\section{Adsorption/desorption isotherms}

Isotherms for each of the four soils were constructed as the amount of adsorbed SCP per gram of soil $\left(\mathrm{C}_{\mathrm{s}}\right.$ ads $)$ as a function of the apparent equilibrium concentration $\left(\mathrm{C}_{\mathrm{aq}}\right)$. The data were well fit using the Freundlich model in logarithmic form (Figure 4), with $r \geq 0.98$ (Table 3).

For soils N2 and S1, the values of $1 / \mathrm{n}$ (Table 3 ) close to unity (0.96) suggest that the sorption is independent of the
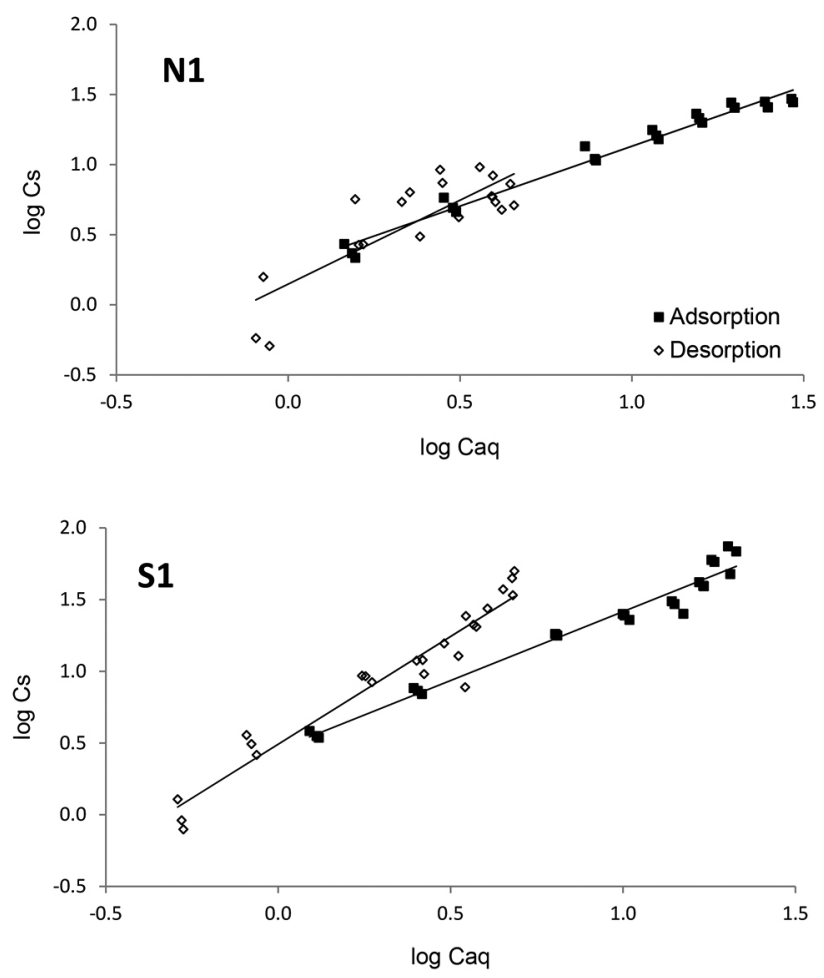

concentration in the tested range and can be approximated with a linear sorption coefficient $\mathrm{K}_{\mathrm{D}}$. For N1 and S2, a lower $1 / \mathrm{n}$ value (0.85) suggests that as the concentration of SCP in the aqueous phase increased, the sorption sites became increasingly saturated and thus less able to sorb additional molecules ${ }^{30}$ i.e., there was a strong interaction between soil and SCP molecules and a decreasing sorption tendency with increasing equilibrium concentration. ${ }^{16,31,32}$ These values fell within the range reported in the literature for SCP (Table 4). In contrast, in a study on the sorption behavior of other sulfonamides (sulfadiazine (SDZ), sulfadimethoxine (SDM), sulfaquinoxaline (SQX) and sulfamethazine
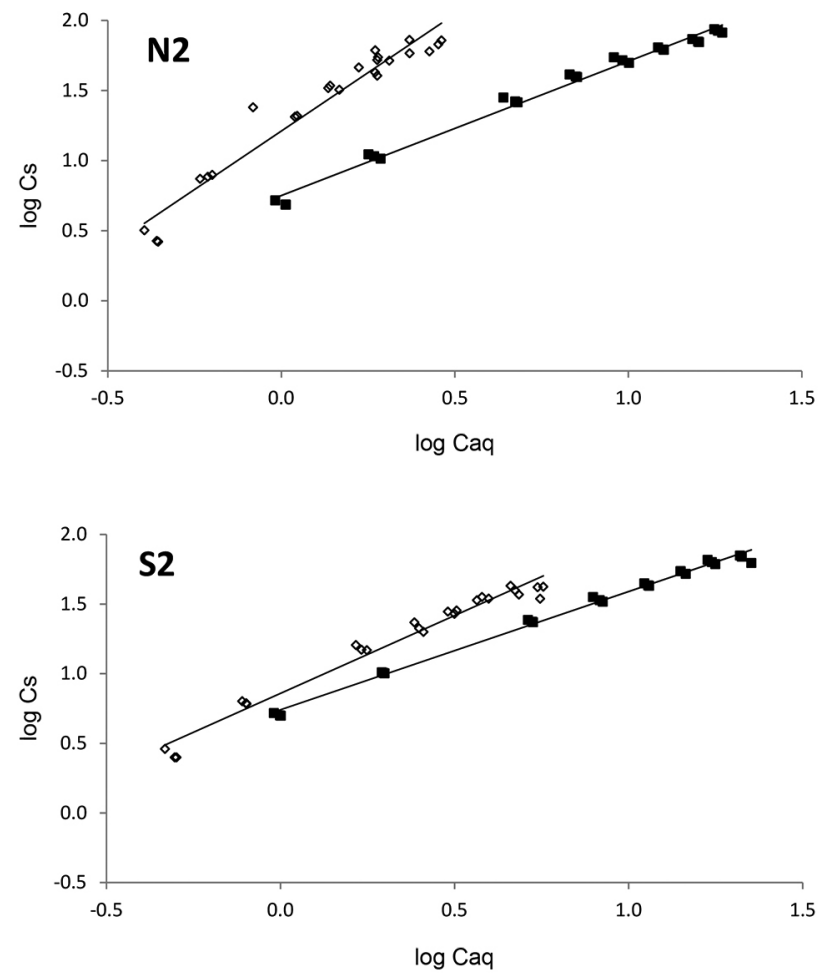

Figure 4. Adsorption ( $\mathbf{\square}$ ) and desorption $(\diamond)$ isotherms for SCP in soils N1, N2, S1 and S2.

Table 3. Values determined from the adsorption and desorption of SCP: distribution coefficient $\left(\mathrm{K}_{\mathrm{D}}\right)$, Freundlich coefficient $\left(\mathrm{K}_{\mathrm{F}}\right)$, Freundlich exponent $(1 / \mathrm{n})$ and adsorption coefficient normalized to organic carbon $\left(\mathrm{K}_{\mathrm{oc}}\right)$

\begin{tabular}{|c|c|c|c|c|c|c|c|}
\hline \multirow{2}{*}{ Soil } & \multirow{2}{*}{ Study } & \multicolumn{2}{|c|}{ Linear } & \multicolumn{3}{|c|}{ Freundlich } & \multirow{2}{*}{$\mathrm{K}_{\mathrm{OC}} /\left(\mathrm{cm}^{3} \mathrm{~g}^{-1}\right)$} \\
\hline & & $\mathrm{K}_{\mathrm{D}}{ }^{\mathrm{a}} /\left(\mathrm{cm}^{3} \mathrm{~g}^{-1}\right)$ & $\mathrm{r}$ & $\mathrm{K}_{\mathrm{F}} /\left(\mu \mathrm{g}^{1-1 / \mathrm{n}}\left(\mathrm{cm}^{3}\right)^{1 / \mathrm{n}}\right)$ & $1 / \mathrm{n}$ & $\mathrm{R}$ & \\
\hline \multirow[t]{2}{*}{ N1 } & $\mathrm{Ads}^{\mathrm{b}}$ & $1.0(0.6)$ & 0.96 & $1.9(4.8)$ & $0.9(1.2)$ & 0.99 & 112 \\
\hline & $\operatorname{Des}^{c}$ & $1.7(5.2)$ & 0.77 & $1.0(1.5)$ & $1.2(4.2)$ & 0.83 & \\
\hline \multirow[t]{2}{*}{$\mathrm{N} 2$} & $\mathrm{Ads}^{\mathrm{b}}$ & $4.5(2.3)$ & 0.99 & $5.6(2.6)$ & $0.9(1.1)$ & 0.99 & 268 \\
\hline & $\operatorname{Des}^{\mathrm{c}}$ & $29.0(2.5)$ & 0.97 & $16.3(3.4)$ & $1.7(1.5)$ & 0.97 & \\
\hline \multirow[t]{2}{*}{ S1 } & $\mathrm{Ads}^{\mathrm{b}}$ & $2.8(1.0)$ & 0.94 & $2.9(2.1)$ & $1.0(0.8)$ & 0.98 & 196 \\
\hline & $\operatorname{Des}^{\mathrm{c}}$ & $8.6(0.1)$ & 0.90 & $3.1(3.9)$ & $1.5(1.8)$ & 0.96 & \\
\hline \multirow[t]{2}{*}{$\mathrm{S} 2$} & $\mathrm{Ads}^{\mathrm{b}}$ & $3.2(2.1)$ & 0.98 & $5.5(0.8)$ & $0.9(0.4)$ & 1.00 & 168 \\
\hline & $\operatorname{Des}^{\mathrm{c}}$ & $7.8(2.1)$ & 0.97 & $7.2(2.0)$ & $1.1(0.7)$ & 0.99 & \\
\hline
\end{tabular}

${ }^{\mathrm{a}}$ Values in parentheses refer to the standard deviation $(\mathrm{n}=3)$; ${ }^{\mathrm{b}}$ Ads: adsorption; ${ }^{\mathrm{C}}$ Des: desorption. 
$(\mathrm{SMZ})$ ) in the same soils (N1, N2, S1 and S2), Doretto and Rath ${ }^{16}$ and Doretto et al. ${ }^{17}$ identified nonlinear sorption isotherms, with $1 / \mathrm{n}$ ranging from 0.70 to 0.94 . Thiele-Bruhn and Aust ${ }^{33}$ observed an increase in isotherm linearity for many sulfonamides after adding pig slurry to soils. The authors assumed that the decrease in nonlinearity indicates decreased site specificity of sulfonamide adsorption in the presence of manure.

The sorption coefficients ranged from 1.0 to $4.5 \mathrm{~cm}^{3} \mathrm{~g}^{-1}$ for $\mathrm{K}_{\mathrm{D}}$ and from 1.9 to $5.6 \mu \mathrm{g}^{1-1 / \mathrm{n}}\left(\mathrm{cm}^{3}\right)^{1 / n} \mathrm{~g}^{-1}$ for $\mathrm{K}_{\mathrm{F}}$. The $\mathrm{K}_{\mathrm{D}}$ values reported from various studies (Table 4 ) range from 0.4 to $70.1 \mathrm{~cm}^{3} \mathrm{~g}^{-1}$, with a mean of $8.8 \mathrm{~cm}^{3} \mathrm{~g}^{-1}$ and a median value of $4.6 \mathrm{~cm}^{3} \mathrm{~g}^{-1}$, which indicates that SCP adsorption is generally low in most soils, although ter Laak et al. ${ }^{18}$ and Leal et al. ${ }^{20}$ showed that for $\mathrm{SCP}, \mathrm{K}_{\mathrm{D}}$ can vary by as much as 100 times depending on the soil, indicating variation in leaching potential.

The adsorption of SCP was higher in the clay soils $(\mathrm{N} 2>\mathrm{S} 2>\mathrm{S} 1)$ than in the sandy soil $(\mathrm{N} 1)$. The $\mathrm{K}_{\mathrm{F}}$ values were positively correlated with clay content $(r=0.92)$, OC content $(r=0.91)$ and CEC $(r=0.80)$ and negatively correlated with sand content $(\mathrm{r}=-0.88)$.

The sorption process of organic compounds in soil depends on the soil composition relative to its organic

Table 4. Comparison of the $\mathrm{K}_{\mathrm{D}}, \mathrm{K}_{\mathrm{F}}, 1 / \mathrm{n}$ and $\mathrm{r}^{2}$ values reported in the literature for SCP sorption on soils

\begin{tabular}{|c|c|c|c|c|c|c|c|c|c|c|c|}
\hline & \multirow{2}{*}{$\mathrm{OC} / \%$} & \multicolumn{3}{|c|}{ Particle size / \% } & \multirow{2}{*}{$\mathrm{pH}$} & \multirow{2}{*}{ CEC } & \multirow{2}{*}{$\begin{array}{c}\mathrm{K}_{\mathrm{D}} / \\
\left(\mathrm{L} \mathrm{kg}^{-1}\right)\end{array}$} & \multirow{2}{*}{$\mathrm{K}_{\mathrm{F}}^{\mathrm{a}, \mathrm{b}}$} & \multirow{2}{*}{$1 / \mathrm{n}$} & \multirow{2}{*}{$r^{2}$} & \multirow{2}{*}{ Reference } \\
\hline & & Clay & Silt & Sand & & & & & & & \\
\hline Clay loam & - & - & - & - & - & - & 1.8 & - & 0.97 & - & 13 \\
\hline Sandy loam & - & - & - & - & - & - & 0.9 & - & 0.91 & - & \\
\hline Matawhero (silt loam) & 2.1 & 27 & 62 & 11 & 6.1 & $15.4^{\mathrm{a}}$ & 1.87 & $3.27^{\mathrm{b}}$ & 0.76 & 0.96 & 11 \\
\hline Te Kowhai (silt loam) & 5.0 & 37 & 54 & 9 & 6.7 & $22.3^{\mathrm{a}}$ & 5.07 & $8.01^{\mathrm{b}}$ & 0.80 & 0.99 & \\
\hline Hamilton (clay loam) & 4.0 & 30 & 51 & 19 & 5.8 & $21.5^{\mathrm{a}}$ & 9.53 & $14.49^{\mathrm{b}}$ & 0.83 & 0.99 & \\
\hline Horotiu (siltloam) & 8.2 & 17 & 48 & 34 & 5.7 & $35.6^{\mathrm{a}}$ & 10.59 & $10.98^{\mathrm{b}}$ & 0.93 & 0.99 & \\
\hline Manawatu (sandy) & 3.3 & 2 & 11 & 87 & 5.1 & $9.7^{\mathrm{a}}$ & 8.60 & $11.47^{\mathrm{b}}$ & 0.85 & 1.00 & \\
\hline Gibsons (sandy loam) & 1.1 & 14 & 41 & 45 & 6.9 & $7.6^{\mathrm{a}}$ & 8.76 & $10.11^{\mathrm{b}}$ & 0.87 & 0.80 & \\
\hline Clay loam & 3.1 & 25.1 & 32.3 & 42.6 & 6.8 & $22.4^{\mathrm{c}}$ & - & $2.5^{\mathrm{d}}$ & - & 0.98 & 18 \\
\hline Loamy sand & 2.2 & 10.3 & 20.5 & 69.2 & 6.9 & $11.4^{\mathrm{c}}$ & - & $1.5^{\mathrm{d}}$ & - & 0.98 & \\
\hline Boxtel (river bank) & 2.2 & 5.8 & - & - & 6.09 & $8.91^{\mathrm{e}}$ & 2.4 & - & - & - & 33 \\
\hline Eendenkooi & 2.2 & 51.6 & - & - & 5.59 & $24.84^{\mathrm{e}}$ & 3.7 & - & - & - & \\
\hline Eijsdens (river bank) & 3.2 & 10.0 & - & - & 7.24 & $13.07^{\mathrm{e}}$ & 0.9 & - & - & - & \\
\hline Eijsden & 3.9 & 13.3 & - & - & 7.38 & $20.52^{\mathrm{e}}$ & 0.9 & - & - & - & \\
\hline Ermelo & 2.5 & 0.2 & - & - & 3.41 & $1.61^{\mathrm{e}}$ & 8.1 & - & - & - & \\
\hline Hank (estuarine river bank) & 5.9 & 8.2 & - & - & 7.36 & $39.33^{e}$ & 2.4 & - & - & - & \\
\hline Lheembroekerzand & 7.0 & 1.4 & - & - & 3.59 & $2.74^{\mathrm{e}}$ & 15.0 & - & - & - & \\
\hline Maatheide & 3.1 & 1.2 & - & - & 6.33 & $4.18^{\mathrm{e}}$ & 5.1 & - & - & - & \\
\hline Niewerkerk & 2.6 & 11.2 & - & - & 7.35 & $12.47^{\mathrm{e}}$ & 0.4 & - & - & - & \\
\hline Oudekerk a/d/ Ijssel & 12.2 & 27.3 & - & - & 4.88 & $39.04^{\mathrm{e}}$ & 34.8 & - & - & - & \\
\hline Valkenswaard & 4.5 & 1.3 & - & - & 4.55 & $2.39^{\mathrm{e}}$ & 2.3 & - & & & \\
\hline Waukegan (silt loam) & 1.8 & 23.6 & 56.5 & 19.9 & 7.5 & - & - & $6.11^{\mathrm{a}}$ & 0.88 & 0.88 & 34 \\
\hline Princeton (sandy soil) & 0.94 & 3.8 & 2.7 & 93.5 & 7.2 & - & - & $3.97^{\mathrm{a}}$ & 0.78 & 0.87 & \\
\hline TypicHapludox & 1.24 & 18.1 & 4.0 & 77.9 & 3.7 & $35.7^{\mathrm{f}}$ & 1.6 & - & - & - & 20 \\
\hline RhodicEutrudox & 9.56 & 68.4 & 20.7 & 10.9 & 6.9 & $52.2^{\mathrm{f}}$ & 6.1 & - & - & - & \\
\hline ArenicHapludult & 0.67 & 6.0 & 10.0 & 84.0 & 5.1 & $32.0^{\mathrm{f}}$ & 0.7 & - & - & - & \\
\hline TypicHapludalf & 4.10 & 36.6 & 44.8 & 18.6 & 5.7 & $217.5^{\mathrm{f}}$ & 5.3 & - & - & - & \\
\hline TypicQuartzipsamment & 0.96 & 8.0 & 4.0 & 88.0 & 3.8 & $27.6^{\mathrm{f}}$ & 1.1 & - & - & - & \\
\hline Lithic Udordent & 2.62 & 14.2 & 34.6 & 51.2 & 4.8 & $153.2^{\mathrm{f}}$ & 7.0 & - & - & - & \\
\hline TypicHapludult & 5.43 & 34.5 & 18.2 & 47.3 & 5.1 & $125.2^{\mathrm{f}}$ & 8.2 & - & - & - & \\
\hline KandiudalficEutrudox & 6.56 & 65.8 & 26.7 & 7.5 & 5.2 & $107.2^{\mathrm{f}}$ & 41.9 & - & - & - & \\
\hline TypicEutroquox & 21.34 & 47.6 & 38.0 & 14.4 & 3.9 & $109.9^{\mathrm{f}}$ & 70.1 & - & - & - & \\
\hline TypicDystrochept & 2.92 & 24.3 & 10.1 & 65.6 & 3.7 & $56.9^{\mathrm{f}}$ & 4.6 & - & - & - & \\
\hline ArenicAlbaqult & 2.16 & 20.4 & 34.7 & 44.9 & 4.8 & $100^{\mathrm{f}}$ & 6.7 & - & - & - & \\
\hline ArenicHapludalf & 0.98 & 4.0 & 24.0 & 72.0 & 4.5 & $39.2^{\mathrm{f}}$ & 1.3 & - & - & - & \\
\hline TypicArquidoll & 5.78 & 54.3 & 25.1 & 20.6 & 5.4 & $207.8^{\mathrm{f}}$ & 13.3 & - & - & - & \\
\hline
\end{tabular}

${ }^{\mathrm{a}} \mathrm{cmol}_{\mathrm{c}} \mathrm{kg}^{-1} ;{ }^{\mathrm{b}} \mathrm{mE}_{\mathrm{q}} / 100 \mathrm{~g} ;{ }^{\mathrm{c}} \mathrm{\mu g}^{1-1 / \mathrm{n}} \mathrm{g}^{-1} \mathrm{~mL}^{1 / \mathrm{n}} ;{ }^{\mathrm{d}} \mathrm{L} \mathrm{kg}^{-1}$; ${ }^{\mathrm{e}} \mathrm{mmol}$ per $100 \mathrm{~g} ;{ }^{\mathrm{f}} \mathrm{mmol}_{\mathrm{c}} \mathrm{dm}^{-3}$; OC: organic carbon; CEC: cation exchange capacity. 
matter content, the composition of the mineral fraction (sand, silt and clay) and soil properties, including porosity, specific surface area and cation exchange capacity. It is also related to the physicochemical properties of the organic molecules, particularly the $\mathrm{pH}$-dependent fraction of cationic, neutral or anionic species that are present. ${ }^{17,35} \mathrm{It}$ can therefore be expected that the $\mathrm{pH}$ of the soil suspension affects the sorption behavior of SCP in soil. ter Laak et al. ${ }^{36}$ for example, showed that increasing $\mathrm{pH}$ (4 to 7) decreased the $K_{D}$ values of SCP $\left(9\right.$ to $<1 \mathrm{~L} \mathrm{~kg}^{-1}$ ), likely because $\mathrm{SCP}^{-}$, which increases in concentration at higher $\mathrm{pH}$ levels (Figure 5), is more soluble than the neutral SCP species and also because of the electrostatic repulsion of $\mathrm{SCP}^{-}$from increasingly negatively charged soil surfaces.

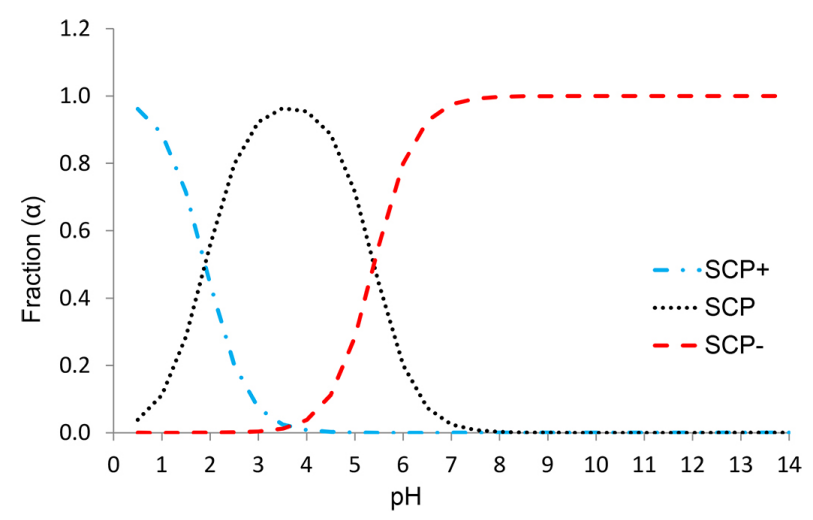

Figure 5. Speciation of $\mathrm{SCP}$ as a function of $\mathrm{pH}$.

Nevertheless, in our study, the $\mathrm{pH}$ of the soils ranged from 4.1 to 5.0 (Table 1). SCP can therefore be assumed to be primarily in its neutral form, and it can be expected that sorption is primarily governed by the hydrophobic partition with the soil organic matter (SOM). Nevertheless, when the partition coefficients $\left(\mathrm{K}_{\mathrm{D}}\right)$ were normalized to the OC content of the soil (equation 6), the resulting $\mathrm{K}_{\mathrm{OC}}$ varied from 112 to $268 \mathrm{~cm}^{3} \mathrm{~g}^{-1}$ (Table 3), and the highest $\mathrm{K}_{\mathrm{OC}}$ value was observed for N2, which was the soil with the highest clay content. These results demonstrate that SCP sorption cannot be solely attributed to hydrophobic partitioning to soil organic matter and are in agreement with Tolls, ${ }^{37}$ who determined that sorption of sulfonamides is mostly driven by electrostatic forces in varying combination with hydrophobic partitioning, particularly for soils at $\mathrm{pH}>5.5$. Nevertheless, many studies have suggested that OC plays a major role in the sorption of sulfonamides to soils and sediments. . $^{38,39}$

Thiele-Bruhn and Aust $^{33}$ reported a higher adsorption of sulfonamides in soils with higher OM content, although this relationship appears to be valid only when considering soil organomineral particles. Thiele-Bruhn ${ }^{1}$ also claimed that the effect of SOM on sulfonamide adsorption depends not only on its quantity but also on its composition. Thiele-Bruhn and Aust ${ }^{33}$ showed that soil sorption coefficients decreased in the presence of pig slurry, which is rich in organic matter, and considered that the mobilizing effect was first related to competitive adsorption between dissolved organic matter that originated from the manure and the sulfonamides.

The low $K_{D}$ and $K_{F}$ values are in the same range as those generally reported for SCP in many other soils (Table 4) and confirm the high potential mobility of SCP in soils, particularly those with high sand $(>70 \%)$, low OC $(<1.5 \%)$, and low CEC $\left(<15 \mathrm{mmol}_{\mathrm{c}} \mathrm{dm}^{3}\right)$ contents, as reported by Leal et al..$^{20}$ Nevertheless, in soils with high OC (> 5.8\%) and clay (> 47.6\%) contents and relatively high CEC $\left(>96 \mathrm{mmol}_{\mathrm{c}} \mathrm{dm}^{3}\right)$, these authors found $\mathrm{K}_{\mathrm{D}}$ values ranging from 14.3 to $70.1 \mathrm{~L} \mathrm{~kg}^{-1}$.

The $\mathrm{K}_{\mathrm{F}}$ values reported by Doretto et al. ${ }^{16,17}$ for other sulfonamides (SDZ, SDM, SQX and SMZ) in the same soils (N1, N2, S1 and S2) were also low, ranging from 1.4 to $19.0 \mu \mathrm{g}^{1-1 / \mathrm{n}}\left(\mathrm{cm}^{3}\right)^{1 / n} \mathrm{~g}^{-1}$. Doretto et al. ${ }^{17}$ showed a clear relationship between $\mathrm{K}_{\mathrm{F}}$ and sulfonamide $\mathrm{K}_{\mathrm{OW}}$, which describes the propensity of the neutral molecules to dissolve in an apolar medium. The highest Freundlich coefficients (5.5 to $29.0 \mu \mathrm{g} \mathrm{g}^{1-1 / \mathrm{n}}\left(\mathrm{cm}^{3}\right)^{1 / n} \mathrm{~g}^{-1}$ ) were observed for SQX $\left(K_{O W}=47.9\right)$, and SDZ $\left(K_{O W}=0.813\right)$ presented the lowest Freundlich coefficients $\left(0.45-2.6 \mu \mathrm{g}^{1-1 / \mathrm{n}}\left(\mathrm{cm}^{3}\right)^{1 / \mathrm{n}} \mathrm{g}^{-1}\right)$. In the present study, an intermediate $\mathrm{K}_{\mathrm{F}}(1.9$ to $\left.5.6 \mu \mathrm{g}^{1-1 / \mathrm{n}}\left(\mathrm{cm}^{3}\right)^{1 / \mathrm{n}} \mathrm{g}^{-1}\right)$ was determined for SCP with $\mathrm{K}_{\mathrm{OW}}=2.0$, supporting the conclusion that SCP partitioning in acidic soils is primarily governed by hydrophobic partitioning of the neutral species to the organic fraction of the soil. Notably, SCP and SDZ are the most similar compounds among the sulfonamides already studied in soils N1, N2, S1 and S2, differing only by the presence of one $\mathrm{Cl}$ on the pyridazine moiety. For both compounds, the sorption followed exactly the same sorption trend of $\mathrm{N} 1<\mathrm{S} 1<\mathrm{S} 2<\mathrm{N} 2$, suggesting that the structure of the molecule is a mandatory parameter in sorption behavior.

The desorption isotherms (Figure 4) were determined according to the procedure used for the adsorption isotherms and represent the amount of SCP still adsorbed per gram of soil as a function of the equilibrium concentration after one desorption cycle. The data from the desorption experiment fit the logarithmic Freundlich isotherms well for all soils, as indicated by the linear regression coefficients $(0.98 \leq r \leq 0.99)$ (Table 3$)$. The desorption $K_{F}$ and $\mathrm{K}_{\mathrm{D}}$ values were consistently higher than those obtained for the adsorption coefficients, indicating that SCP is retained on soil after one desorption cycle. The highest Freundlich desorption coefficient value $\left(36 \mu \mathrm{g}^{1-1 / \mathrm{n}}\left(\mathrm{cm}^{3}\right)^{1 / \mathrm{n}}\right)$ was observed for soil N2, suggesting that this soil, which 
contained large amounts of clay, had a lower desorption capacity.

The sorption study showed that, as generally observed for other sulfonamides, SCP has a low sorption potential at a natural acidic $\mathrm{pH}$ (4.1-5) of these soils, suggesting that this antimicrobial might reach surface water and groundwater. The presence of SCP in leachate samples from soil column amended with pig slurry enriched with SCP supports this hypothesis..$^{40}$ Recent studies have shown that the dissipation in the environment of organic contaminants such as veterinary antibiotics can occurred via abiotic and biotic processes..$^{41,42}$ Nevertheless, several studies also revealed the presence of numerous veterinary antibiotic residue classes in surface waters and ground waters close to agricultural areas. ${ }^{41,43,44}$ The analysis of 39 groundwater samples taken in seven different groundwater bodies of Catalonia under a relevant agricultural pressure revealed the presence of at least 15 different sulfonamides in concentration up to $274 \mathrm{ng} \mathrm{L}^{-1}$, but SCP was not determined. ${ }^{45}$

\section{Conclusions}

This study has assessed the sorption potential of sulfachloropyridazine in four soils of the textural classes (sandy, sandy-clay and clay) that cover approximately $80 \%$ of the state of São Paulo, which is located in a geographically southern sub-tropical zone.

The results show that adsorption was positively correlated with the organic carbon and clay contents. Nevertheless, at the natural $\mathrm{pH}$ of these soils, the SCP is mainly in its neutral form, and it was possible to confirm that as for other sulfonamides previously studied in the same soils, SCP partitioning should be primarily governed by hydrophobic partitioning of the neutral species to the organic fraction of the soil.

The SCP adsorption followed exactly the same sorption trend of $\mathrm{N} 1<\mathrm{S} 1<\mathrm{S} 2<\mathrm{N} 2$ as sulfadiazine previously studied in the same soils. Because both compounds are very similar, differing only by the presence of one $\mathrm{Cl}$ on the pyridazine group, this suggests that the structure of the molecule is a mandatory parameter in the sorption behavior of sulfonamides.

\section{Acknowledgments}

The authors gratefully acknowledge financial support from Fundação de Amparo à Pesquisa do Estado de São Paulo (FAPESP), Brazil (process 2009/17470-4 and 2013/09543-7) and Conselho Nacional de Desenvolvimento Cientifico e Tecnológico (CNPq), Brazil, and also Embrapa (Jaguariúna, SP) for supplying the soil samples.

\section{References}

1. Thiele-Bruhn, S.; J. Plant Nutr. Soil Sci. 2003, 166, 546.

2. Kolz, A. C.; Ong, S. K.; Moorman, T. B.; Chemosphere 2005 , $60,284$.

3. Diaz-Cruz, S. M.; Garcia-Galan, J. M.; Barcelo, D.; J. Chromatogr. 2008, 1193, 50.

4. Halling-Sorensen, B.; Nielsen, S. N.; Lanzky, P. F.; Ingerslev, F.; Lutzhoft, H. C. H.; Jorgensen, S. E.; Chemosphere 1998, 36, 357.

5. Tolls, J.; Environ. Sci. Technol. 2001, 35, 3397.

6. Sarmah, A. K.; Meyer, M. T.; Boxall, A. B. A.; Chemosphere 2006, 65, 725 .

7. Boxall, A. B. A.; Fogg, L. A.; Blackwell, P. A.; Kay, P.; Pemberton, E. J.; Croxford, A.; Rev. Environ. Contam. Toxicol. 2004, 180, 1.

8. de la Torre, A.; Iglesias, I.; Carballo, M.; Ramirez, P.; Jesus Munoz, M.; Sci. Total Environ. 2012, 414, 672.

9. Ministério da Agricultura, Pecuária e Abastecimento (MAPA); Animal, Mercado Interno, available at http://www.agricultura. gov.br/animal/mercado-interno/producao, accessed in May 2016.

10. Sindicato Nacional da Indústria de Produtos para Saúde Animal (SINDAM), available at http://www.sindan.org.br/sd/base. aspx ? controle=8, accessed in May 2016.

11. Srinivasan, P.; Sarmah, A. K.; Manley-Harris, M.; Sci. Total Environ. 2014, 472, 695.

12. Elsayed, E. M.; Prasher, S. O.; Environ. Sci. Pollut. Res. 2014, $21,3339$.

13. Boxall, A. B. A.; Blackwell, P.; Cavallo, R.; Kay, P.; Tolls, J.; Toxicol. Lett. 2002, 131, 19.

14. MacKay, A. A.; Vasudevan, D.; Environ. Sci. Technol. 2012, 46, 9209.

15. Thiele-Bruhn, S.; J. Plant Nutr. Soil Sci. 2003, 166, 546.

16. Doretto, K. M.; Rath, S.; Chemosphere 2013, 90, 2027.

17. Doretto, K. M.; Peruchi, L. M.; Rath, S.; Sci. Total Environ. 2014, 476, 406.

18. ter Laak, T. L.; Gebbink, W. A.; Tolls, J.; Environ. Toxicol. Chem. 2006, 25, 904.

19. García-Galán, M. J.; Díaz-Cruz, M. S.; Barceló, D.; TrAC, Trends Anal. Chem. 2009, 28, 804.

20. Leal, R. M. P.; Alleoni, L. R. F.; Tornisielo, V. L.; Regitano, J. B.; Chemosphere 2013, 92, 979.

21. Organization for Economic Co-operation and Development (OECD), Test No. 106: Adsorption-Desorption Using a Batch Equilibrium Method; OECD Publishing: Paris, 2000.

22. Plazinski, W.; Rudzinski, W.; Plazinska, A.; Adv. Colloid Interface Sci. 2009, 152, 2.

23. Fernandez-Bayo, J. D.; Nogales, R.; Romero, E.; J. Agric. Food Chem. 2008, 56, 5266.

24. Schwarzenbach, R. P.; Gschwend, P. M.; Imboden, D. M.; Environmental Organic Chemistry, $2^{\text {nd }}$ ed.; John Wiley \& Sons: 
New York, EUA, 1992.

25. Sabljic, A.; Environ. Health Perspect. 1989, 83, 179.

26. Grupta, S. S.; Bhattacharyya, K. G.; Adv. Colloid Interface Sci. 2011, 162, 39.

27. Kahle, M.; Stamm, C.; Chemosphere 2007, 68, 1224.

28. Sanders, S. M.; Srivastava, P.; Feng, Y.; Dane, J. H.; Basile, J.; Barnett, M. O.; J. Environ. Qual. 2008, 37, 1510.

29. Figueroa-Diva, R. A.; Vasudevan, D.; MacKay, A. A.; Chemosphere 2010, 79, 786.

30. Kurwadkar, S. T.; Adams, C. D.; Meyer, M. T.; Kolpin, D. W.; J. Agric. Food Chem. 2007, 55, 1370.

31. Calvet, R.; Environ. Health Perspect. 1989, 83, 145.

32. Singh, N.; J. Agric. Food Chem. 2002, 50, 6434.

33. Thiele-Bruhn, S.; Aust, M. O.; Arch. Environ. Contam. Toxicol. 2004, 47, 31.

34. Accinelli, C.; Koskinen, W. C.; Becker, J. M.; J. Agric. Food Chem. 2007, 55, 2677.

35. MacKay, A. A.; Vasudevan, D.; Environ. Sci. Technol. 2012, 46, 9209

36. ter Laak, T. L.; Gebbink, W. A.; Tolls, J.; Environ. Toxicol. Chem. 2006, 25, 933.

37. Tolls, J.; Environ. Sci. Technol. 2001, 35, 3397.

38. Kahle, M.; Stamm, C.; Chemosphere 2007, 68, 1224.
39. Sukul, P.; Lamshoeft, M.; Zuehlke, S.; Spiteller, M.; Chemosphere 2008, 73, 1344.

40. Blackwell, P. A.; Kay, P.; Ashauer, R.; Boxall, A. B. A.; Chemosphere 2009, 75, 13.

41. Kim, K.-R.; Owens, G.; Kwon, S.-I.; So, K.-H.; Lee, D.-B.; Ok, Y. S.; Water, Air, Soil Pollut. 2011, 214, 163.

42. Pan, M.; Chu, L. M.; Sci. Total Environ. 2016, 545, 48.

43. Solliec, M.; Roy-Lachapelle, A.; Gasser, M.-O.; Coté, C.; Généreux, M.; Sauvé, S.; Sci. Total Environ. 2016, 543, 524.

44. Javid, A.; Mesdaghinia, A.; Nasseri, S.; Mahvi, A. H.; Alimohammadi, M.; Gharibi, H.; J. Environ. Health Sci. Eng. 2016, 14,4 .

45. García-Galán, M. J.; Garrido, T.; Fraile, J.; Ginebreda, A.; DíazCruz, M. S.; Barceló, D.; Anal. Bioanal. Chem. 2011, 399, 795.

Submitted: November 5, 2015 Published online: May 19, 2016

FAPESP has sponsored the publication of this article. 